\title{
Da matriz historicista ao holismo metodológico no institucionalismo vebleniano *
}

\author{
Vagner Luís da Silva ${ }^{* *}$
}

\begin{abstract}
Resumo
$\mathrm{O}$ artigo procura, de modo geral, realçar o papel de Thorstein Veblen na história do pensamento econômico, retomando um dos mais originais críticos do capitalismo norte-americano de fins do século XIX e princípios do XX. Para tanto, o debate que empreendemos concentrar-se-á na abordagem de três tópicos importantes do chamado institucionalismo vebleniano, mas pouco destacados nas discussões do tema: (1) o diálogo com o historicismo alemão e sua influência no universo disciplinar da economia, (2) a incerta defesa do indutivismo como tática investigativa e (3) a percepção do holismo metodológico como a postura mais singular dos textos veblenianos, em franca oposição à tradição neoclássica de época.
\end{abstract}

Palavras-chave: Veblen, 1857-1929; Institucionalismo, Historicismo, Indução, Holismo.

\section{Abstract \\ From the historicist matrix to the methodological holism in Veblenian institucionalism}

This article, in general, enhances the role of Thorstein Veblen in the history of economic thought by taking up one of the original critics of American capitalism of the late nineteenth and early twentieth centuries. Thus, the debate that we have undertaken will focus on addressing three key topics of the so called Veblenian institutionalism, but little prominent in the theme discussions: (1) dialogue with the German historicism and its influence in the discipline universe of economics, (2) the uncertain defense of the inductivism as investigative tactics and (3) the perception of the methodological holism as the most natural posture of the Veblenian texts in overt opposition to the neoclassic tradition of the time.

Keywords: Veblen, Institutionalism, Historicism, Induction, Holism.

JEL B15, B41.

\section{Introdução}

Thorstein Bunde Veblen (1857-1929) foi responsável por uma obra ampla, com ressonâncias na economia e na sociologia norte-americanas de fins do século XIX e princípios do XX. Com um comportamento pouco convencional, entrou para a história do pensamento econômico como $o$ principal fundador do institucionalismo, corrente de investigação econômica baseada, entre outras características, na oposição aos neoclássicos, na incorporação da história e de elementos interpretativos das ciências sociais. Tomado como um outsider entre os

\footnotetext{
* Trabalho recebido em 13 de agosto de 2010 e aprovado em 3 de julho de 2012.

*** Professor do Instituto Federal de Educação, Ciência e Tecnologia São Paulo (IFSP), São Paulo, SP, Brasil. E-mail: vagnersilva125@gmail.com.
} 
economistas, Veblen é com certa frequência desprezado pelos adeptos das correntes majoritárias de investigação na área. Situado num canto um pouco obscuro da teoria social, sobretudo quando visto da perspectiva contemporânea, o autor alcançou, porém, um inusitado prestígio a sua época.

Com o objetivo de retomar aspectos importantes do institucionalismo de um de seus fundadores e principal expoente, empreendemos, a seguir, um debate em torno de três pontos fundamentais em Veblen. Primeiro, a presença do historicismo no cenário acadêmico norte-americano e a influência do historicismo europeu na obra do autor, seus limites e os desdobramentos desse contexto em favor de uma metodologia de investigação que se opunha ao marginalismo de então. Segundo, a incerta defesa do indutivismo como o método mais adequado à corrente institucionalista. E, por fim, fazendo jus ao clássico debate que polarizava o Homo Economicus ao Homo Sociologicus - ou o individualismo metodológico do agente maximizador de resultados ao holismo metodológico dos fatores sociais -, levamos adiante uma argumentação acerca da sutil opção vebleniana pela segunda posição. De modo geral, pretende-se, assim, compor um painel razoável que permita uma maior compreensão de um autor por vezes desprezado pelo pensamento econômico tanto quanto pelo pensamento sociológico a despeito de seu enorme esforço em aproximar os dois universos disciplinares ${ }^{1}$.

\section{A ascendência do historicismo alemão}

O século XIX foi propício para o surgimento de sistemas de pensamento que se referenciavam por algum tipo de historicismo. A influência dos debates que se desenrolavam na filosofia europeia contaminou, em algum grau, todos aqueles que se aventuravam na interpretação da sociedade, sendo o apego à história como componente explicativo um sintoma mais ou menos comum entre eles. $\mathrm{O}$ historicismo que nesse contexto brotou não se reduzia a um conjunto de características definitivas, antes padecia de variados sentidos; prestava-se tanto aos radicalismos quanto aos propósitos conservadores de uma teoria social politicamente mais à direita (Nisbet, 1980, p. 147).

(1) A biografia de Veblen pode ser consultada no extenso trabalho de Dorfman — Thorstein Veblen and his America (1934). Muito embora seja a principal fonte de consulta para os pesquisadores que se dedicam ao cientista social, o ensaio biográfico foi escrito num momento em que os arquivos relativos à vida de Veblen ainda não estavam disponíveis ao público, o que, conforme Tilman, não desabona o esforço e o resultado final produzido por Dorfman (1994, p. 456). Edgell, no entanto, salienta que, em seu trabalho, Dorfman não se opôs à mitificação de um Veblen outsider, sendo, na verdade, um dos principais responsáveis por difundi-la. Essa versão biográfica, que aliou pobreza e marginalidade como fatores de um Veblen contestador, sofreu, a partir dos anos 90, algumas correções (Edgell, 1996, p. 630). Galbraith avalia que a pobreza dos Veblen foi um mito bem sucedido criado e amplamente divulgado por Dorfman. Com base nas propriedades da família e em cartas arquivadas na Sociedade Histórica de Minnesota, Galbraith mostrou como os irmãos de Veblen divertiam-se ou zangavam-se com a lenda de sua origem miserável (1980, p. 141-142). 
Numa compreensão mais ampla, o historicismo tomava o processo histórico como raiz para a organização dos discursos filosóficos, sociológicos ou econômicos, não sendo incomum a aceitação de leis gerais que pronunciavam certo determinismo no entendimento da dinâmica social. De modo mais específico, foi certa tendência da filosofia alemã, da segunda metade do século XIX em diante, a responsável por reforçar temas sensíveis às forças histórico-sociais, em muito recusando o determinismo disperso de época. Do historicismo alemão nasceram, e seguiram por rumos diversos, os trabalhos de Max Weber, Georg Simmel e Wilhelm Dilthey, por exemplo. Em suas características gerais encontramos, entre outras, a rejeição às considerações abstratas e totalizantes em proveito das que tomam o processo histórico numa perspectiva individual, material e temporalmente definida, sendo o objeto do conhecimento histórico-social dotado de alguma especificidade. A incorporação do empirismo define algo mais do historicismo alemão, tanto quanto a recusa da explicação causal própria das ciências naturais e a adoção do método compreensivo (Verstehen) como instrumento do conhecimento histórico - tema metodológico ampliado, sobretudo, na sociologia weberiana (Reale; Antiseri, 1991, p. 453-454).

O historicismo que abundava na filosofia alemã não deixaria de impregnar a sociologia ou a economia nacional do período. Os economistas alemães viram-se diante de imensas possibilidades com a sugestiva sofisticação que as demais ciências sociais atingiam, evidenciando uma classe de problemas que ultrapassava o universo disciplinar da economia. Considere-se, ainda, que, por força do nacionalismo germânico, as obras dos clássicos ingleses ou franceses, popularizadas na primeira metade do século XIX, não impactaram os economistas alemães em proporções razoáveis (Spengler; Allen, 1971, p. 499). Por outro lado, é aceitável que a sombra de Hegel, Marx e do Romantismo tenha recaído sobre a filosofia do país, atingindo, por conseguinte, os esforços intelectuais que levavam adiante as pesquisas e conjecturas das ciências sociais ${ }^{2}$.

Como apontaram Spengler e Allen, a abordagem dos problemas sociais e a definição de um método na economia da Escola Histórica alemã, como fícou conhecida, poderiam contemplar alguns atributos gerais, naturalmente refletindo as discussões do historicismo na filosofia. Um deles era enfatizar a acumulação de "dados positivos" acerca da amplitude e variedade das condutas sociais com o propósito de evidenciar a forma que as tendências econômicas assumem e procurando ressaltar a ausência de um caráter universal para elas. Outro considerava a possibilidade de incorporar "tendências ou leis de desenvolvimento econômico" ou "etapas através das quais uma economia [poderia] evoluir", não

(2) Paula, estabelecendo as "afinidades eletivas" entre tradições intelectuais e culturais, alude ao poder do Romantismo na filosofia e na literatura e seu impacto na interpretação econômica em fins do século XIX e princípios do XX (2005, p. 87). 
desprezando, contudo, uma "intervenção coletiva e consciente" na dinâmica econômica (1971, p. 499).

Releve-se, porém, que esses pontos somente são tomados de uma forma muito generalizada, pois, de resto, também é distintivo, entre tais economistas, a ausência de propostas homogêneas que serviriam para dar alguma coesão ao grupo. Pautando-nos pela análise de Spengler e Allen, outros atributos gerais podem ser enumerados aqui. Primeiro, a crítica aos economistas clássicos, notadamente Ricardo, e neoclássicos em virtude da insistência em considerar como invariáveis as condutas humanas e as formas institucionais delas oriundas, perspectivas que sustentavam uma metodologia dedutiva. O historicismo econômico era avesso ao "método abstrato" e às "hipóteses impossíveis de verificação", lastreadas em dados econômicos "universalmente válidos e imutáveis" e tomando a ação social em "termos puramente individualistas"; preferiam privilegiar uma análise que partia da sociedade, revelando as "considerações não econômicas" que governavam as atitudes econômicas do indivíduo, isto é, evidenciando o caráter cultural presente no universo da economia (Spengler; Allen, 1971, p. 500-501).

Outro ponto saliente, comum na generalidade das premissas econômicas da Escola Histórica alemã, diz respeito à aceitação de estágios de desenvolvimento socioeconômicos (Spengler; Allen, 1971, p. 501). Um celebrado economista dessa escola, Gustav Schmoller, estudando a história alemã, por exemplo, distinguiu cinco etapas de seu desenvolvimento: aldeã, cidadã, territorial, nacional e mundial. Foi com alguma frequência que tais etapas foram delineadas também entre outros autores com o objetivo de elaborar estudos comparativos entre regiões ou países, os quais, por sua vez, serviam de base para a prescrição de políticas públicas que pudessem resultar em desenvolvimento nacional.

Nesse sentido, entre tais economistas, o papel do Estado foi realçado como articulador maior da dinâmica econômica, tendo em vista a possibilidade de realizações coletivas - é claro que sem a conotação socialista que noutros tempos a economia estatal adquiriria. As noções de iniciativa e liberdade individual, tão presentes na intelectualidade anglo-americana, foram menos absorvidas pelos germânicos.

Ao Estado, como algo mais que um "instrumento político destinado a preservar a lei e a ordem" e como "organismo social" dotado de um soberano poder administrativo, tanto cabia ajudar os indivíduos na definição de seus fins quanto auxiliar as empresas privadas no desenvolvimento das condições gerais de produção que elas por si só não conseguiam realizar (Spengler; Allen, 1971, p. 502). Para os historicistas, tratava-se de, sob a direção estatal da economia, fazer com que o retardatário desenvolvimento industrial do país avançasse para competir com o potencial econômico da Europa Ocidental (Paula, 2005, p. 81). Os trabalhos 
normativos que o historicismo alemão produzia impunham um Estado forte e preocupado com o crescimento e a solidez da economia nacional, mas também com reformas sociais: "por esta razão, era necessário um detalhado estudo dos problemas econômicos particulares e suas possíveis soluções, assim como das medidas políticas que deviam ser adotadas" (Spengler; Allen, 1971, p. 502).

Num enfoque mais preciso da história do pensamento econômico, Schumpeter procurou dividir o historicismo alemão em dois momentos: a velha escola histórica e a nova escola histórica (1964, p. 76). A primeira, referenciada por nomes como Bruno Hildebrand e Karl Knies; a segunda, tendo Schmoller como liderança marcante. Ainda, segundo Schumpeter, foi Schmoller quem configurou uma "escola" historicista propriamente dita, "transformada numa verdadeira potência científica, aparecendo, em outros países, movimentos análogos ou, pelo menos, influenciados por ela" (Schumpeter, 1968, p. 165).

Ligeiras diferenças, contudo, assinalam os limites entre ambas, sendo a primeira versão muito envolvida pelas generalidades típicas do historicismo que se pronunciou no pensamento alemão por todo o século XIX. À segunda vertente coube a tarefa de ajustar o foco da pesquisa, incorporando muito mais a história e preocupada com o papel que ela deveria ter numa análise econômica. Não por outro motivo é que o historicismo econômico alemão confunde-se com a segunda corrente, pois ela significou um avanço em termos metodológicos, enquanto a primeira sequer conseguiu se notabilizar como escola (Schumpeter, 1964, p. 7677).

Abordar o historicismo econômico alemão, porém, implica em compreender um pouco mais de suas inclinações metodológicas. A aversão ao individualismo maximizador é uma delas, pois esses economistas entendiam que as soluções para os problemas econômicos pesquisados só poderiam adquirir algum sentido se fossem incorporados outros elementos de análise como instituições, valores sociais, padrões de conduta em sociedade, vistos como especificidades culturais através da história. Por consequência, uma abordagem multidisciplinar somente poderia ser alcançada despindo-se por completo da rigidez da análise econômica atomista e hipotética. Por outro lado, como observou Paula, aos alemães restava somente uma "estratégia de superação de seu atraso relativo" e, contra o individualismo metodológico, encontrar uma matriz de análise "alternativa às dos países avançados" (2005, p. 89). Seguindo esse rumo, Schmoller acentuou a recusa em se apegar, como Comte o fizera, às leis históricas definitivas como fontes exclusivas da interpretação econômica, tomadas como "caricaturas da realidade" e demasiado "erro naturalista" (Schumpeter, 1964, p. 78).

O indutivismo, portanto, parecia dizer mais respeito aos propósitos dos historicistas do que os métodos abstratos que tanto fecundaram a tradição 
neoclássica. A especulação teórica, fragilmente presa a premissas alheias aos acontecimentos do mundo real, foi encarada como insuficiente pela metodologia histórica que preferia a observação e generalização de episódios singulares para a estruturação de sistemas interpretativos mais complexos. Seus esforços empíricos na acumulação de dados históricos, no reconhecimento de casos particulares, no uso da estatística, na descrição de eventos econômicos foram empregados na análise dos conflitos de classe, da dinâmica dos grandes conglomerados industriais, do papel dos sindicatos, das políticas públicas organizadas pelo Estado, entre outros temas ${ }^{3}$.

Alguns dos princípios constitutivos do historicismo econômico alemão e sua oposição ao marginalismo também estão presentes em Veblen. Porém, antes de avaliarmos o diálogo do autor com a corrente historicista, é preciso observar a forma como tal escola se fez representar na academia norte-americana; afinal, o universo da economia no país não permaneceu imune aos desdobramentos de um debate que já avançava pelo continente europeu.

A abundante representação acadêmica do marginalismo nas fronteiras anglo-saxãs não constituiu obstáculo suficiente de modo a evitar que o historicismo alemão seduzisse novos adeptos. Estudantes de pós-graduação norte-americanos buscaram na Alemanha uma formação complementar em economia e acabaram absorvendo muito da alternativa historicista que por lá já ganhara terreno - com nomes como Richard T. Ely, Edwin R. A. Seligman e John B. Clark, por exemplo (Seckler, 1977, p. 44) ${ }^{4}$.

Os trabalhos desses economistas, empreendidos nas universidades norteamericanas nas décadas finais do século XIX, tanto se prestaram a tornar o debate acadêmico mais plural, competindo com a poderosa influência marginalista, como serviram para reposicionar a investigação na área em novos níveis de análise, orientados pela pretensão de transpor os fenômenos econômicos de superfície. Os

(3) De certo modo, as posições metodológicas de base dedutiva levadas adiante pelos neoclássicos realçaram as concepções indutivas do historicismo alemão. Esse conflito intelectual alcançou maior relevo quando Schmoller criticou, por volta de 1880, os ensaios metodológicos de C. Menger, autor de referência do marginalismo austríaco. O episódio, conhecido como "Batalha dos Métodos" (Methodenstreit), serviu, dali por diante, para cristalizar os limites de interesse daqueles que se orientavam por uma ou outra posição (Schumpeter, 1964, p. 81). O desenvolvimento das argumentações de Menger e Schmoller não deixou de ser matizado pela vigorosa demarcação de fronteiras, o que, segundo Schumpeter, é usual em qualquer contenda metodológica envolvendo teorias, escolas, tradições: "as escolas genuínas são fenômenos sociológicos [...] têm suas estruturas — relações entre líderes e liderados — suas bandeiras, seus gritos de guerra, seus impulsos e seus interesses humanos" (1964, p. 82). Porém, apesar dos limites estabelecidos com certa contundência, Menger não se privou de defender posteriormente a necessidade da história como componente explicativo. Schmoller, por sua vez, admitiu certa semelhança nos esforços das ciências sociais com os princípios de causalidade das ciências naturais, pois reconheceu, como objetivo maior da pesquisa científica, a "explicação dos fenômenos sociais por meio das relações de causa e efeito ou de leis”, encaradas por ele como sinônimos (Schumpeter, 1968, p. 180).

(4) Clark fora professor de Veblen no Carleton College. 
estudos seguiram uma metodologia "mais empírica, mais orientada para os problemas práticos, mais estatística e menos reduzida em seu campo de ação", ampliando o enfoque para "as finanças públicas, ferrovias, agricultura, questões trabalhistas, tecnologia, o impacto da legislação econômica, os ciclos econômicos" (Spengler; Allen, 1971, p. 504).

Se o marginalismo convinha muito bem a um discurso liberal, ausentando o Estado de responsabilidade social, o historicismo norte-americano apontou em sentido contrário. Considerando as fortes ondulações da economia norte-americana após a Guerra Civil (1860-1865), com o impacto da industrialização e da imigração, a concentração de riqueza e a especulação financeira, coroadas pelo empobrecimento dos centros urbanos, é possível conjecturar, salvo melhor razão, que a produção historicista como que se emparelhou com o discurso reformista da ocasião.

Não sem frequência os trabalhos adotaram um tom prescritivo, propugnando políticas públicas claramente redistributivas que pudessem sanear a instabilidade social do período. Ademais, orientando-nos pelas peculiaridades da economia do país, é razoável aceitar que o historicismo norte-americano, tal qual na Alemanha, teria como propósito não declarado contornar os perigos da indeterminação da identidade nacional, sob ameaça, na segunda metade do XIX, por conta da veloz industrialização e suas consequências no deslocamento de populações (Ross, 1997, p. 218).

Os historicistas norte-americanos tiveram na American Economic Association um núcleo que aglutinava muitos de seus representantes, inicialmente como "um lugar aberto ao vento da revolta" e que se opunha às "abordagens do tipo laissez-faire" (Lallement, 2006, p. 384). Apesar de certa preocupação de seus fundadores de que a associação fosse confundida com uma agência de propaganda do historicismo alemão, o compromisso original da organização tanto procurou se vincular aos métodos históricos, agregando os fenômenos culturais e a indução no rol de suas preocupações, como incluiu o Estado como instrumento do progresso social e condição do desenvolvimento econômico (Seckler, 1977, p. 46; 49-51).

Os desdobramentos do historicismo norte-americano, porém, não levaram a totalidade de seus adeptos para posições extremas e irreconciliáveis em relação à economia neoclássica. Antes, pode-se notar uma aproximação da perspectiva de alguns de seus autores com aquelas defendidas na tradição liberal. Avessos a qualquer incoerência metodológica, um certo historicismo liberal, como definiu Ross, procurou alinhar-se às premissas do marginalismo. Para o caso, as expectativas de sucesso de reformas liberais que pudessem se sintonizar com o mercado e a preservação institucional da dinâmica econômica capitalista em muito diziam respeito a esses intelectuais (Ross, 1997, p. 188-190). 
A despeito dos avanços e recuos dos estudos historicistas nos Estados Unidos frente ao discurso neoclássico, tal corrente não pôde desfrutar da consolidação de seu arsenal investigativo - seja porque no historicismo houvesse vestígios da esquerda europeia, seja porque persistia um preconceito da economia tradicional em relação à história, vista como uma disciplina menor. No primeiro caso, considere-se que os métodos difundiram-se a partir da Alemanha, defendendo um forte apego ao Estado como agente do desenvolvimento socioeconômico. No segundo, destaque-se que a história norte-americana, como campo de investigação, carecia da grandeza e da complexidade que a disciplina dispunha na academia alemã (Ross, 1997, p. 200).

Nesse sentido, o descolamento entre a história e a economia, nos Estados Unidos, enfraqueceu o historicismo no país, de modo a dificultar a sua permanência como corrente alternativa de longo prazo, tendo sequer chegado com vigor ao século XX. As condições de época, com o impacto da industrialização e as demais transformações econômicas que resultaram na sublimação do mercado, fizeram com que o ambiente universitário se rendesse ao marginalismo, coroado como o instrumento investigativo mais adequado àquela atmosfera ${ }^{5}$.

\section{O diálogo com a corrente historicista}

A influência do historicismo sobre a teoria vebleniana pareceu seguir um roteiro germânico mais do que norte-americano. Não que Veblen não tivesse tido contato algum com as discussões ou com a produção acadêmica dos historicistas dos Estados Unidos, disso não restam dúvidas. Mas a aproximação entre alguns dos economistas dessa corrente e uma interpretação mais liberal, conveniente com aspectos metodológicos neoclássicos e com o padrão de acumulação capitalista, por si só repeliria os esforços de coerência da obra vebleniana.

Já a parcela do historicismo norte-americano mais afeito a remodelar a conduta do Estado, sintonizando-se com o reformismo social e político daquelas circunstâncias históricas e crítico contumaz da estrutura industrial monopolista e do mercado socialmente excludente, parece ter exercido alguma atração sobre o autor. Metodologicamente, os historicistas do país referenciavam-se em muitos graus pelo historicismo alemão; nesse sentido, Veblen associou-se às premissas dessa forma de investigação socioeconômica, considerando os recursos histórico-culturais e demais categorias de análise como bases de um bem-sucedido estudo de caso. É possível que o peso da tradição germânica tenha comprimido muito da autonomia do historicismo anglo-saxônico, de modo que o segundo, ao que parece,

(5) Saliente-se, porém, como sugere Arida, que o sucesso e a permanência do programa neoclássico frente aos seus concorrentes, em fins do século XIX, resultaram, em boa medida, da "superioridade de [seus] procedimentos retóricos" e de seu "vigor comparativo", para os quais a evidência empírica não constituiu fator relevante por conta de sua insuficiência em demarcar a vitória de uma teoria sobre a outra (2003, p. 25). 
palidamente representou a força do primeiro. De qualquer forma, Veblen não desfrutou de nenhuma imunidade quanto ao discurso que centralizava a história como componente explicativo da argumentação sociológica ou econômica, sendo plausível aceitar que sua orientação fosse antes pela originalidade germânica do que pelos esforços acadêmicos dos seus conterrâneos ${ }^{6}$.

Se, do ponto de vista metodológico, a inclinação antineoclássica de Veblen harmonizou-se com o historicismo alemão, o autor, porém, não fez eco à totalidade das análises empreendidas por essa corrente investigativa. Menos do que se submeter a elas indistintamente, Veblen levantou sérias dúvidas sobre a possibilidade de êxito das investigações levadas adiante pelos economistas históricos. Suas críticas apontavam para um conjunto de falhas que tanto tinham a ver com a influência da tradição filosófica do país quanto com a prática de um estudo que se esforçava por manter um tom mais normativo, ainda que implícito.

Sua argumentação foi dirigida contra as premissas econômicas de Schmoller por aceitá-lo como o acadêmico mais bem-sucedido entre os adeptos do historicismo germânico, capaz de superar algumas das inconsistências oriundas dos economistas da primeira metade do século XIX. Veblen demonstra particular consideração por esse autor, tomando-o como o grande responsável pela estruturação científica da economia historicista, encorpando-a com recursos metodológicos mais rigorosos e eficientes do que até então se vira (1969, p. 255 256).

A despeito do aparente acolhimento do historicismo, Veblen, contudo, apontou o inevitável determinismo que pairava sobre os que dele se apropriavam. Não sem frequência, os acadêmicos dessa corrente sofriam de certa inclinação teleológica, fixando a naturalidade dos eventos estudados em termos causais mais simples do que a realidade de fato apresentava.

Claro que os historicistas alemães, sobretudo Schmoller e aqueles de seu círculo, procuraram fugir dessa tendência determinista. Veblen não chegou a identificar tal economia como uma ciência pós-darwinista, mas distinguiu característicos traços gerais do darwinismo em seus trabalhos, não obstante a "filiação hegeliana" inequivocamente presente em seus raciocínios encadeados pela história (1969, p. 265). Portanto, é preciso indagar sobre a capacidade de atração da monumental herança historicista entre os germânicos - lastreada por nomes como Hegel e Marx e referenciada pelo abrangente determinismo das mais variadas espécies que compunha a atmosfera do século XIX - e de reação objetiva daqueles que se aventuravam pelos recursos históricos. Afinal, como Veblen apontou, muito da composição causal, apresentada como resultado da economia historicista, tanto

(6) Conforme avaliação de Seckler: "não há dúvida de que [...] a escola [historicista] na economia política norte-americana quase não era mais que uma encarnação da escola histórica alemã” (1977, p. 51). 
se esforçou por se isentar de fórmulas deterministas que acabou sendo por elas vitimada. Considere-se, ainda, o viés prescritivo dos trabalhos desse círculo, pautados pela pouca vocação para a neutralidade e propensos a aceitar um projeto intervencionista de Estado, e teremos novos elementos capazes de viciar o arsenal investigativo de qualquer economista dessa corrente.

Veblen não tinha qualquer condescendência teórica com as propostas deterministas, criticando as análises que estreitavam a relação de causa e efeito com vistas a um encadeamento já presumido (1969, p. 73-74; 182-183). Apesar das singularidades do debate envolvendo causalidade, apurados no século XVIII pela filosofia iluminista, a natureza da compreensão teórica no universo econômico reproduzia as circunstâncias mais gerais de época, portanto, disposta a aceitar uma propensão melhorativa que a história apresentava e esperava da sociedade, fruto do desenvolvimento tecnológico de cada ocasião (1932, p. 363-370).

Conforme a posição vebleniana, a referência aos usos políticos que se faz de um programa investigativo que não só supõe o seu resultado mas que alicerça seus projetos de intervenção em convicções rarefeitas marca antes um retrocesso do que um avanço em qualquer disciplina acadêmica. Até por isso, Veblen identificou a crença em uma "tendência melhorativa no curso dos eventos culturais" presente na obra de Schmoller, denotando um vício interpretativo que se arrastava por força das concepções de época (1969, p. 263). Destaque-se que o autor pouco se afeiçoou aos esforços científicos considerados pré-darwinistas, qualificação dada por ele aos que insistiam no agrupamento de dados estéreis e, sobretudo, numa linearidade viciada tipicamente determinista (1969, p. 36-37).

A crítica vebleniana continua, pois sua proposta de uma economia evolucionária não aceitava a redução taxonômica apresentada nos trabalhos de Schmoller como exemplo de investigação econômica adequada. O equívoco, segundo Veblen, residiria no fato de os historicistas dessa linha "gastarem suas energias sobre um trabalho descritivo", cuja atenção voltava-se apenas para o "escrutínio de detalhes históricos" sem ponderar a complexidade do processo de mudança (1969, p. 263-264). Perdem-se na acumulação de dados, imaginando deles obter as referências para uma interpretação que contemple um respeitável grau de certeza sobre um caso particular para, enfim, explicar suas relações causais de modo definitivo. Recorde-se, do item anterior, que Schmoller avaliava a explicação de causa e efeito como patrimônio da investigação científica, aceitandoa, no limite, como sinônimo de lei (Schumpeter, 1968, p. 180). Ocorre que a adesão à causalidade entre os historicistas estava atrelada ao acúmulo de dados históricos e estatísticos, tomados como sucessão de eventos e desprovidos de dinâmica, com as análises frequentemente se perdendo nos vínculos entre antecedentes e consequentes sem atribuir à relação um caráter processual (Veblen, 1969, p. 263; 267-269). 
Não por outro motivo, Veblen considerou a economia historicista germânica demasiadamente narrativa, sendo incapaz de propor uma explicação estrutural que avançasse para além das fronteiras dos elementos coletados e quantitativamente organizados em termos de generalizações empíricas. $\mathrm{O}$ foco exagerado na descrição das etapas do processo tanto quanto os insistentes relatos etnográficos envolvidos por uma pessoal noção de cultura e moral que particularmente interessavam a Schmoller impediam o historicismo de notar o desenrolar do movimento histórico; faltava-lhe uma teoria do processo em si que se ajustasse à interpretação genética (Veblen, 1969, p. 268-269).

Tal teoria somente poderia se estruturar adequando-se ao projeto evolucionista, definido por uma ciência social pós-darwinista, responsável pela incorporação da mudança consecutiva como base para o entendimento dos nexos causais. Uma interpretação que seguisse esse rumo seria a única tática viável para se fugir da causação histórica determinista, segundo Veblen (1969, p. 37).

Não era o caso do historicismo da escola alemã e tampouco de Schmoller. De acordo com o autor, entre eles, não somente a investigação do desenvolvimento cultural vinha acompanhada de pré-concepções, como ainda não havia a preocupação adequada em relação à análise das causas que marcam os desdobramentos históricos, sendo elas geralmente reduzidas a um tratamento estatístico ou a uma coleção de fatos. As causas, conforme Veblen, responsáveis pela "determinação do curso dos eventos" e pela "uniformidade ou variação das seqüências", receberam de Schmoller escassa atenção, implicando em "generalizações mais ou menos arbitrárias" antes que numa teoria do processo histórico (1969, p. 262).

Veblen ironizou, nesse tipo de historicismo, a possibilidade de se extrair "leis naturais" originadas de pesquisas empíricas: "são [tais leis] coloridas pelas tendências ou idéias do investigador" (1969, p. 262), acrescentando que a produção historicista teria como resultado:

\footnotetext{
[...] um corpo de sabedoria aforístico, talvez belo e valioso em sua espécie, mas completamente pretensioso quando medido pelos padrões e objetivos da ciência moderna. Como bem se sabe, nenhum ganho teórico substancial foi produzido por essa linha histórico-romântica de investigação e especulação, aparentemente pela razão de que não há leis culturais nesse tipo de investigação, além das imprecisas generalidades que são suficientemente familiares de antemão para todos os adultos razoavelmente inteligentes (Veblen, 1969, p. 262).
}

Uma vez aplainado o terreno que permite melhor observar a natureza metodológica do historicismo, é lícito retomar os elementos que aproximam Veblen de tal escola de pensamento. Inicialmente, recordamos a semelhança de ambos na crítica à economia neoclássica. Se o historicismo capitaneado por Schmoller pouco se afeiçoou à postura metodológica da ciência econômica que 
passou a imperar a partir da segunda metade do século XIX, Veblen, em igual medida, dela desconfiou. Ambos se opuseram à sublimação de um mercado que se referenciava pela vontade particular ou, em outras palavras, discordaram de que o bem-estar social poderia naturalmente se originar das demandas privadas, pois, metodologicamente, os autores contestaram a adoção da racionalidade individual, bem como sua suposta propensão para maximizar resultados, como raiz para o entendimento da dinâmica socioeconômica ${ }^{7}$.

As críticas encaminhadas por Schmoller e demais historicistas são ligeiramente anteriores aos melhores argumentos de Veblen, considerando, ainda, toda a sorte de oposições que brotaram em maior ou menor grau contra as posições marginalistas já nas últimas décadas do século XIX. A teoria vebleniana, formada em meio à evolução desse debate, acumulou um arsenal crítico que por ele se orientou. Ademais, o paralelo metodológico entre Veblen e historicistas tinha por vocação descaracterizar a tendência de singularizar o sujeito social na compreensão dos destinos econômicos da sociedade em proveito de interpretações sociológicas, antropológicas e históricas que produzissem melhores efeitos na constatação do universo econômico. Por isso a cultura adquiriu alguma centralidade nas análises desse tipo. Para ambas as correntes, a viabilidade de se tomar objetivamente os desejos individuais de satisfação e a propensão ao acúmulo de vantagens ou a capacidade de quantificar o comportamento racional nas relações mercadológicas, corolários de uma explicação marginalista, sustentavam-se em terreno movediço, pois excluíam uma abordagem totalizante dos fenômenos sociais ${ }^{8}$.

Tanto para os historicistas quanto para Veblen, tal abordagem ancorava-se numa análise diacrônica, pautando-se pela expectativa de solucionar o encadeamento coerente dos eventos históricos a partir de sua relação causal. Porém, ambos não se furtavam de investigar as especificidades do problema ou objeto de análise, procurando fugir de uma explicação definitiva que exclusivamente partisse ou chegasse a generalizações deterministas e viciadas apesar de Veblen duvidar do sucesso de Schmoller e demais historicistas em produzir resultados antideterministas. A teoria vebleniana, nesse sentido, foi inequivocamente tributária dos desdobramentos mais amplos do historicismo alemão, em cuja natureza residia certa inclinação para aceitar a variabilidade dos fenômenos sociais.

(7) Segundo Veblen, a postura metodológica neoclássica procura compensar, como fatores objetivos, elementos que têm uma dimensão subjetiva, que estão presos, portanto, num "encadeamento social necessário e nem sempre aparente" (Silva, 2008, p. 140).

(8) O conceito de equilíbrio entre os neoclássicos era fortemente criticado por Veblen, de tal modo que Hodgson alinhou o autor norte-americano aos "grandes heréticos do pensamento econômico", como Marx e Keynes, principais responsáveis por ampliar o escopo da economia para além da "obsessiva teorização do equilíbrio" (1988, p. 140). 
Como bem vimos em parágrafos anteriores, o historicismo de Schmoller seguiu por um viés normativo, tendo o Estado um papel importante no desenvolvimento econômico. Não é, porém, o caso de encontrarmos em Veblen tal intenção. Sua teoria institucional não apontou para soluções e tampouco patrocinou qualquer discurso intervencionista. A coisa mais próxima disso, mas nem por isso admitindo um tom prescritivo, é seu discreto elogio do instinto da produção e sua feroz desqualificação do instinto predatório - como se pode observar em The Theory of Business Enterprise (1932) ou The Vested Interests and the Common Man (1964a) ${ }^{9}$. Não que o autor tenha produzido um manifesto incisivo em favor da tomada de poder pelas classes produtoras. Contudo, conforme o arranjo levado adiante em The Engineers and the Price System (1965b), somente a imposição do saber técnico, dos engenheiros e da ciência, da capacidade operária estimularia a ruptura do poder da classe ociosa.

Não temos, portanto, nenhuma semelhança entre o intervencionismo de Schmoller e as utopias de Veblen. É certo, porém, que o autor procurou se opor às estratégias especulativas de acumulação tanto quanto àqueles que se referenciavam pelo status do consumo, alinhando-se, talvez sem muita convicção, ao grupo dos descontentes do qual participavam os socialistas da ocasião. Sua incerteza no que diz respeito à vocação da classe trabalhadora para um poder coletivo pautou-se pela incorporação dos mesmos padrões de consumo, ostentação e status próprios dos poderosos que Veblen tanto criticara em The Theory of the Leisure Class (1934) ${ }^{10}$ sendo os trabalhadores como que envolvidos pela falsa consciência de que falavam os marxistas ${ }^{11}$. De qualquer forma, como sinalizou Dugger, é sensível, na teoria vebleniana, o mesmo ceticismo e oposição ao laissez-faire anglo-saxônico que animou o historicismo intervencionista de Schmoller, considerando, no entanto, que ambos rumaram para diferentes destinos (1994, p. 238).

Seckler minimizou o debate levado adiante por Veblen contra algumas posições historicistas, procurando distanciar o autor de qualquer influência daquela corrente. Sugeriu, com certo exagero, que Veblen tinha "o maior desprezo tanto [em relação] à escola histórica de economia quanto à filosofia da história", apesar de admitir a "coincidência de seus escritos" com as controvérsias historicistas (1977, p. 56). Sem avançar nas observações veblenianas que polarizaram com o historicismo germânico e sem discutir a convergência metodológica de ambos,

(9) Os instintos da produção e o predatório são centrais nas obras de Veblen, o primeiro como "agente da dinâmica, da realização, do empreendimento, da conquista ou da organização" e o segundo como "instrumento da destruição, da exploração ou do atraso" (Silva, 2010, p. 295).

(10) A Teoria da Classe Ociosa, na edição brasileira de 1965.

(11) Por conta da análise de Veblen que avançava nesse rumo e dada sua contribuição para a atmosfera de contestação daquelas circunstâncias históricas, na qual estavam imersas distintas correntes socialistas, Ross o definiu como o Gramsci norte-americano (1997, p. 207). 
Seckler não conseguiu corroborar sua afirmação sobre o "desprezo" vebleniano. De resto, imaginou imunizar o teórico quanto ao contexto de época, garantindo-lhe alguma aura de autonomia.

Sublinhe-se, ainda, que a crítica vebleniana padeceu de alguma insuficiência em alcançar os complexos mecanismos da reprodução capitalista, se quisermos fazer eco às posições de Adorno. Apesar do alinhamento de Veblen com as interpretações historicistas, atreladas à suposição de uma inexorável causalidade que se orienta antes pela permanência de instituições bem adaptadas, o autor procurou enfatizar a sua insatisfação quanto às teorias deterministas envolvidas, segundo ele, por certo vício teleológico. O que pode parecer coerência com a noção de causalidade darwinista antes denota alguma fragilidade da crítica vebleniana da estrutura econômica, pois, conforme Adorno, assim como o teórico afiançou em Marx o vir a ser de um socialismo definitivo, cuja essência encontrava-se carregada por algo do determinismo hegeliano, a teoria institucional de Veblen supôs uma causalidade cumulativa, representando ela própria a expressão de uma dinâmica que também se caracterizava por um viés evolutivo. Em Marx, salienta-se o otimismo de uma evolução social para além da opressão de classes, mas, em Veblen, a evolução não resulta em modificações positivas, senão aquelas que apenas institucionalizam novos mecanismos de dominação (Adorno, 1994, p. 14 17).

Assim, a inviabilidade de uma teoria crítica vebleniana, sugere Adorno, resume-se ao seu modelo interpretativo de curto alcance permeado por argumentos que desabonam a cultura do consumo, da luxúria, do status, do ócio, mas, por conta do distanciamento da inspiração dialética, tal modelo evidencia ineficiência em demonstrar os atributos da contradição essencial de um sistema de poder. $\mathrm{Na}$ perspectiva de um frankfurtiano, em Veblen não poderíamos encontrar algo diferente do que se apresenta: a dualidade marcada pelos hábitos de pensamento produtivo e predatório, circunscrevendo, na agenda do primeiro, a criatividade, a cooperação e o empreendimento desinteressado do lucro, e pautando o segundo pela destruição baseada nas vantagens pessoais, na ostentação e na competição agressiva. Em tais condições, o instinto da produção parece emergir como o demiurgo redentor da humanidade materializado na eficiência tecnocrática que suplantaria as concepções pecuniárias de vida. Contudo, na contrapartida da teoria crítica de Adorno, a cristalização dessa nova estrutura de poder apenas substituiria uma opressão por outra (1994, p. 12-16).

Para além do historicismo, é conveniente, ao menos, situar Veblen e o institucionalismo no amplo mosaico das manifestações culturais da belle époque, 
que tanto se esparramava pela Europa quanto pela América ${ }^{12}$. Seguindo essa pista, Paula conjecturou que o institucionalismo pudesse representar o contraponto, na ciência econômica, "ao que nas artes plásticas, na literatura, na música, mas também na física" foi subscrito pelas manifestações do "Simbolismo, pelo Impressionismo, pela física quântica e pela física probabilística" $(2005$, p. 84). O autor ponderou que a "busca da representação do mundo mediante as percepções cambiantes da cor, da luz, do tempo, das sensações", observada nas obras de Monet, Debussy, Rimbaud, Proust, Joyce ou de Planck, contribuiu para que a "pretensão nomológica do determinismo estreito" fosse perturbada pelo "reconhecimento da indeterminação, do acaso, da incerteza" (Paula, 2005, p. 84).

É possível presumir que Veblen, em alguma medida, impregnou-se do debate cultural da belle époque, mas, além das conjecturas, salvo melhor juízo, é elementar tomá-lo como produto de seu tempo e dos argumentos dispersos da ocasião, ressaltando que tanto deles se utilizou quanto deles eventualmente procurou se distanciar. Num caso ou no outro, inevitavelmente partilhou do contexto de época, tornando-se porta-voz, na economia, daqueles que mais efetivamente procuraram contrariar o determinismo ou o racionalismo.

Nesse sentido, é sintomática a presença de fragmentos do pragmatismo nos argumentos de Veblen, como é o caso das noções de instinto e hábito. Entre outras características, os hábitos na teoria vebleniana são definidos numa dimensão social como "atitudes pretéritas incorporadas de modo usual" que se transformam em referência para toda a sociedade, de tal modo que os indivíduos refletem tais práticas como "naturais, intemporais ou mesmo necessárias" (Silva, 2010, p. 298). Contudo, Hodgson argumenta que a psicologia das propensões instintivas, de Willian James, já sugeria, à época, que a ação poderia resultar de hábitos tidos como "comportamento não-reflexivo fruto de situações repetitivas" (1998, p. 177 78). John Dewey também difundiu a noção de hábito como meio para fixar ações e comportamentos sociais rotineiros, conforme Waller (1993, p. 12). E Charles S. Peirce, por sua vez, justificava o papel dos hábitos na conservação de padrões de comportamento social cristalizados desde longa data (Waller, 1993, p. 10-11). A despeito da influência difusa de época, em Veblen, o conceito de hábito absorve a influência do pragmatismo, mas adquire uma dimensão um pouco mais elástica que a pretendida pelos seus contemporâneos. No autor institucionalista, o hábito aparece como desdobramento necessário do conceito de instinto ou de disposição instintiva e meio através do qual se definem as instituições. Assim, são as

(12) Segundo Monastério, Veblen não usou o termo institucionalismo para sua teoria, com a expressão consagrando-se somente nos anos 30 (1998, p. 39). Lallement informa, no entanto, que o termo institucionalista passou a identificar os adeptos do estudo das instituições na ciência econômica, orientação investigativa já presente entre os historicistas norte-americanos na virada do século XIX ao XX, e explicitada nos estatutos da American Economic Association de 1918 (2006, p. 385). 
consequências sociais do hábito — hábito de pensamento tornado hábito de vida (Veblen, 1969, p. 38) — que são relevantes para a institucionalização de práticas coletivas, normas sociais, padrões de conduta ou regras de comportamento, em detrimento de qualquer traço de escolha racional dos indivíduos.

Por fim, quanto às dificuldades na permanência do institucionalismo vebleniano, é necessário ressaltar que alguns de seus componentes teóricos pareciam, a partir da segunda década do século XX, já não mais encontrar lugar no debate acadêmico - como as próprias noções de instinto ou hábito, por exemplo. Confirmando essa posição, Hodgson recorda que ocorreram mudanças profundas nas ciências sociais entre 1910 e 1940, momento em que muito da psicologia norteamericana, baseada em propensões instintivas, e da filosofia pragmática foram obscurecidos pelo positivismo filosófico e pela psicologia comportamental (1998, p. 167). Influenciado difusamente por aquela psicologia e pelo pragmatismo, o institucionalismo vebleniano, ao que parece, também se viu abandonado à própria sorte diante do impacto da interpretação comportamental ou do peso da análise neoclássica e de seu contraponto mais bem-sucedido, o keynesianismo.

\section{A inclinação indutiva}

Não esgotamos, até o momento, as relações possíveis da teoria vebleniana com o historicismo alemão, pois significativa, ainda, é a radical discordância das duas correntes em relação à postura metodológica dedutiva difundida pelos neoclássicos, baseada em prerrogativas que supunham analogias matemáticas e uma economia estática dos processos sociais. Veblen e o historicismo de Schmoller acusavam a matriz neoclássica de se desenvolver em função de uma lógica econômica formal para a qual concorriam premissas arquitetadas a priori, fundamentadas na expectativa de esclarecer os elementos condicionantes do equilíbrio econômico. No limite, o processo de investigação dedutivo remeteria a leis gerais dotadas de um caráter atemporal, servindo para guiar a compreensão dos fenômenos econômicos nas relações sociais.

É certo que Schmoller e os seus, como já observamos, nortearam-se pelo acúmulo empírico de dados, aglutinados com as ferramentas da história e da estatística, no interesse de apreender uma tendência uniforme de desenvolvimento econômico para certo número de fenômenos investigados. Nesse sentido, contrariavam um conhecimento definido exclusivamente pela dedução que desprezasse a corroboração empírica do problema, fazendo do empirismo o meio 
adequado para a consolidação do raciocínio indutivo - usando aqui de certa generalização para o termo ${ }^{13}$.

Assim como os historicistas, Veblen também procurou dar à indução uma condição de destaque na consolidação do conhecimento científico. Fez, em escassas passagens, a defesa de meios indutivos para a condução da análise econômica, supondo que, a partir de tais meios, pudesse abstrair alguma regularidade do processo social:

Exclusivamente pela indução é que podemos reduzir os objetos em sistemas e conexões, e então trazer os objetos particulares e os eventos à sombra de leis definitivas de interação; portanto, somente pela indução podemos ter tal conhecimento nos capacitando para a previsão do futuro; [...] é esse conhecimento único que pode servir como guia na vida prática, seja moral ou de outra natureza (Veblen, 1964b, p. 193).

O indutivismo vebleniano apresenta-se, ao que parece, como um esforço para se constituir numa alternativa viável à dedução neoclássica, partilhando, assim, do empreendimento levado adiante pelos partidários do historicismo. Mas é preciso esclarecer que se o teórico negava o apriorismo de uma economia considerada ortodoxa, não é menos verdade que ele se situasse distante de uma oposição radical às estratégias de investigação dedutivas. Em outras palavras, o autor avaliou negativamente a metodologia neoclássica pelo que ela tinha de incerto, sua aposta no hedonismo incondicional da conduta humana; consequentemente, acabou por alinhar sua argumentação a um viés indutivo, o qual estava presente, como bem sabemos, entre os partidários da escola alemã. Não queremos dizer com isso que Veblen admitiu o empirismo como único meio eficaz de apreender a dinâmica de um problema social. Tomando o conjunto de sua obra como referência, é possível presumir que o autor compactuou menos com o modelo indutivo do que provavelmente o fizeram outros institucionalistas ${ }^{14}$.

Suas opiniões foram construídas tendo em vista a disposição das informações econômicas e do saber etnográfico e histórico de fins do século XIX e começo do XX, fonte de consulta e ponto de partida para a organização de

(13) Frequentemente, toma-se a "indução por enumeração simples" como modelo de raciocínio indutivo, o que não significa que a indução a ela se limite, como apontam Hospers (1984, p. 167-182) e Losee (1979, p. 159-74).

(14) Para ficarmos apenas nos outros dois expoentes do institucionalismo norte-americano da primeira metade do século XX, recordamos que Commons avaliou a relação da economia com o poder judiciário, enquanto Mitchell dedicou-se ao estudo do desenvolvimento econômico a partir do recolhimento de dados estatísticos, “quase que um fim em si mesmo", observou Blaug (1990, p. 510). Gordon reconheceu no indutivismo da tradição institucionalista os seguintes passos: “(1) um problema é identificado, (2) dados relevantes são reunidos, (3) uma hipótese é formulada (sob a influência dos dados), (4) as hipóteses são empiricamente testadas, (5) na tentativa de endossá-las ou rejeitá-las e (6) o argumento dado não garante que a tentativa de endosso representa a verdade final", frequentemente chegando a novos problemas "identificados em um novo passo (1) de um novo ciclo" (1994, p. 375). 
raciocínios que teriam por propósito dar corpo a sua cadeia argumentativa. Tal encadeamento seguia uma lógica muito própria, com a costura de conceitos como instinto, hábitos, status destinados à composição de uma teoria com alguma pretensão de ordem.

Na coleta do saber disponível à época é que reside sua propensão para o modelo indutivo, tática aparentemente capaz de endossar uma melhor compreensão da dinâmica econômica. No entanto, considerando que a indução parte de premissas previamente já constatadas pela experimentação, não devemos excluir que, ao final de um argumento, poderíamos chegar a uma premissa superior e de caráter geral responsável, ela própria, por guiar o processo investigativo, gerando, no limite, um padrão ou uma regularidade nos termos de uma lei. Nesse sentido, a estrutura teórica de Veblen poderia se prestar a uma interpretação que viesse a tomá-la como um esforço inacabado de generalização empírica.

Não fica de todo indefinida a orientação mais ou menos geral que Veblen tomava de suas posições pretéritas para alcançar novos níveis de elaboração teórica, ou seja, não estava destituído de força qualquer raciocínio coerente e já consolidado na estruturação de uma determinada análise. Se for admissível, dessa forma, que muitas de suas conjecturas tenham sido formuladas a partir de elementos concretos da realidade social, com o uso corrente daquilo que já estivesse consagrado, em igual medida não se poderiam inutilizar as abstrações que se orientavam por hipóteses, empenhadas em conduzir explicações causais com certo requinte e suposta precisão. Afinal, Veblen, ao que parece, "pouco se preocupava em aprofundar os fatos da vida econômica", se quisermos concordar com a crítica de Blaug (1990, p. 511).

Suas explicações acerca do nascimento da classe ociosa, da formação dos hábitos de vida e pensamento ou dos processos predatórios, todos alocados em tempos remotos e pouco afeitos à evidência por meio de quaisquer provas, somente podem ser consideradas como suposições e, portanto, produções abstratas que eventualmente partiram de hesitantes elementos materiais. Uma leitura atenta de The Theory of the Leisure Class (1934) encontraria um corpo de ideias bem amarrado, talvez elegante na argumentação, satírico nos exemplos, mas algo distante do que se poderia exatamente definir como empírico. Por outro lado, há, nas posições metodológicas de Veblen, expressas em The Place of Science in Modern Civilization and Other Essays (1969), uma notável recusa na radicalização de processos dedutivos aos quais pudesse se impor um sistema de averiguação de hipóteses, como era próprio dos neoclássicos. Em todo caso, o autor não deixou explícitas considerações acerca do método dedutivo ou indutivo que viessem a esclarecer mais do que até aqui temos discutido. 
O fato é que Veblen não pautou observações que metodologicamente pudessem orientar seus seguidores, no que reside a impossibilidade de uma escola vebleniana. Considerando a relativa variedade de táticas investigativas de outros institucionalistas, como Mitchell e Commons, por exemplo, é fácil compreender a "ausência de consenso no que diz respeito a conceitos e categorias" entre tais pesquisadores, inviabilizando qualquer "homogeneidade em plano e método" na formação de um "sistema unitário" de pensamento (Homan, 1971, p. 540). Não há, portanto, qualquer modelo explícito de investigação que possa ser compartilhado por eventuais adeptos de Veblen, já que suas críticas ao dedutivismo dos neoclássicos não inutilizam o processo dedutivo como tal, assim como suas projeções pouco têm a ver com um exclusivo método indutivo.

No limite, sua obra pode até ser tomada como um esforço de análise histórica de tipo interpretativo, como o fez Homan, aproximando, por exemplo, a economia institucional vebleniana dos trabalhos produzidos por Weber (1971, p. 541). De modo geral, parece razoável aceitar como componente metodológico dos institucionalistas o desenvolvimento de "explanações [que] enfatizam a 'compreensão' em lugar da 'previsão", sendo esse processo apreendido como base sobre a qual se assenta o "entendimento [dos] novos dados" que se apresentam à investigação (Blaug, 1999, p. 162). Nesse rumo, não deixa de ser sugestivo que possíveis tipologias possam ser encontradas em Veblen quando o autor define a classe ociosa, o padrão especulativo baseado no instinto predatório ou o prestígio oriundo do consumo exibicionista. Em vista das possibilidades que o roteiro interpretativo poderia apresentar à teoria vebleniana, ficam ainda mais incertas suas inclinações indutivas como exclusivos recursos metodológicos.

Blaug considera o tema dedução/indução mal formulado nas discussões metodológicas, sendo frequentemente vítima de certa confusão que acaba por reduzi-lo a uma dualidade excludente, pois "supõe que a indução [seja] o oposto de dedução e que esses são os únicos métodos de pensamento lógicos" (1999, p. 54) $)^{15}$. Na sua avaliação, devemos ponderar que a indução padece de um duplo sentido, não sendo incomum a mistura de ambos quando se trata dos argumentos metodológicos que procuram a defesa de métodos indutivos. Primeiro, a indução como "argumento lógico demonstrativo", na expressão de Blaug, que se sustenta em premissas baseadas nas informações "sobre alguns membros de uma classe a fim de apoiar uma generalização sobre toda a classe", inclusos, em tais generalizações, "alguns membros não examinados dessa mesma classe", resultando

(15) Como sublinha o autor: "dificilmente poderá haver algo que confunda mais do que a noção comum de que dedução e indução são operações mentais opostas, com a dedução nos levando do geral ao específico e a indução, do específico ao geral” (Blaug, 1999, p. 54). Hegenberg, em sintonia com a posição de Blaug, recorda que a polarização dedução/indução "é muito simplista", e que a indução comporta "vários tipos de inferência", ressaltando que a conclusão nesse tipo de raciocínio "nunca é certa" e que apenas se estabelece com "determinado grau de probabilidade" (1973, p. 87-88). 
numa conclusão definitiva. Segundo, a indução como argumento "nãodemonstrativo", que defende que "hipóteses específicas são apoiadas por fatos específicos", ou seja, uma indução que não carrega a pretensão de estabelecer verdades definitivas, pois "não pode logicamente excluir a possibilidade de que a conclusão final seja falsa” (Blaug, 1999, p. 53).

A confusão que se estabelece em torno dos exercícios indutivos em alguma razão remete à presumida eficiência lógica da indução clássica que se pauta por argumentos demonstrativos, sendo tal esforço invalidado, em grande medida, desde o "problema da indução" de Hume até a rejeição popperiana dos processos indutivos, tratados como mitos metodológicos, conclui Blaug (1999, p. 52 e 54). Para o caso de Veblen, se quisermos tomá-lo como opositor de uma metodologia dedutiva, devemos fazê-lo somente pelo que ele acreditava ser a base dos processos investigativos da economia ortodoxa reinante em fins do século XIX e começo do $\mathrm{XX}$ - lembrando novamente que o autor agrupou tais economistas pelo que eles aparentemente tinham de genérico, desconsiderando a amplitude da análise neoclássica e aqueles, entre eles, que não descartavam o empirismo em suas investigações. Por outro lado, se quisermos tomar a teoria vebleniana como defensora de uma metodologia indutiva, devemos fazê-lo não nos limites de uma indução definitiva, cujo resultado define-se pela generalização de conclusões absolutas, mas apenas como regra mais ou menos geral sobre a qual se pauta a postura investigativa - provavelmente sem desabonar eventuais abstrações que possam servir para reorientar o discurso, lembrando Blaug do equívoco corriqueiro que opõe a indução à dedução.

Muito da economia do século XIX, sobretudo da segunda metade em diante, requisitava o título de ciência para suas análises. Nesse esforço, os economistas do período regularmente produziram teorias na expectativa de conseguir prever os eventos futuros, pois, em geral, compartilhavam a ideia de testar empiricamente suas soluções teóricas para melhor compreender as consequências da dinâmica econômica. Mesmo que eventualmente subvalorizassem os testes empíricos, como ponderou Blaug, não negavam a ideia de que “"explicar' [era], em última instância, prever [se um] determinado acontecimento poderia ou não ocorrer" (1990, p. 497).

Não foi incomum, porém, que o "apriorismo radical", mesmo lastreado por um sistema de deduções lógicas, não descartasse os testes empíricos na averiguação de suas previsões, tanto quanto o "ultra-empirismo", referenciado primeiro pelos fatos mais do que pelas hipóteses, não inutilizou por completo qualquer processo de abstração (Blaug, 1990, p. 498). A inclinação indutiva de Veblen parece comportar alguma coisa do segundo caso. Não que ele fosse ultraempirista, pois, como vimos, não havia, no autor, uma tendência para enumerar ou esgotar dados, fatos e estatísticas, mas podemos, ao menos, indicar 
uma teoria vebleniana pouco afeita à previsão, esforço típico da economia ortodoxa. Prever não era, para Veblen, um tema incongruente com a ciência econômica desde que se norteasse por meios empíricos e não resultasse em vícios deterministas. Contudo, para o autor, a explicação científica, no caso das ciências sociais, parece circunscrever-se nos limites da compreensão causal, sem maiores traços preditivos - até porque devemos considerar que Veblen em muito se inspira nos estudos darwinistas, cujo esquema teórico explica em termos de causa e efeito, mas não se lhe atribui maior poder de previsão.

Parece-nos bastante claro que se o autor não toma partido do empirismo radical, tampouco o faz em relação ao apriorismo absoluto, permanecendo um tanto incerta a adesão exclusiva a qualquer dessas regras metodológicas dada a insuficiência de provas em contrário. $\mathrm{O}$ alinhamento ao indutivismo, talvez não muito expressivo, implicou na condução de sua metodologia em termos relativos pela falta de um posicionamento explícito diante do debate. Como resultado, Veblen abriu o flanco para ataques que procuraram desacreditar seu corpo teórico e, por consequência, o institucionalismo como ciência econômica.

De fato, muito do que se poderia rotular como institucionalismo ficou à mercê de um invariável ou irregular corpo de práticas investigativas. "Elasticidade metodológica" foi a expressão usada por Homan na tentativa de demonstrar que a economia institucional não conseguiu dar um tratamento coerente e organizado aos dados concretos acumulados empiricamente, os quais, em razão de sua complexidade, poderiam ser investigados a partir de uma variedade de enfoques nem sempre alcançados pelos institucionalistas (1971, p. 537).

Blaug não fez melhor juízo dos métodos da economia institucional. Apesar de não aglutiná-la numa metodologia única, sua crítica aponta pelo menos algumas tendências em comum: a oposição às noções de equilíbrio e comportamento racional e a aceitação dos costumes como componente explicativo. No entanto, dada sua disposição em aceitar o arsenal metodológico neoclássico, o referido autor procurou destacar que muito do que se convencionou como método institucional poderia ser reduzido ao "ato de contar histórias", cuja natureza seria mais bem sintetizada pelo método da "coligação", típico entre os historiadores. Tal método guia-se pelo "ajuntamento de fatos, generalizações de pouca abrangência, teorias de alto nível e julgamentos de valor em uma narrativa coerente". Blaug ironiza: "Em mãos hábeis, pode ser extremamente persuasivo, e ainda assim nunca é fácil explicar posteriormente porque houve a persuasão" (1999, p. 163).

Muito do que em Veblen se apresenta como teoria, simplifica Blaug com algum exagero, poderia ser tomado como descrição, articulado numa dualidade que se arrasta por toda a obra do autor, opondo o que é útil ao que é inútil, sem potencial explicativo ou qualquer possibilidade de verificação (1990, p. 512). 
Entretanto, a capacidade da tradição econômica neoclássica em superar as controvérsias teóricas e em se estabelecer como visão dominante explica, em alguma medida, a incompatibilidade do institucionalismo com uma metodologia bem definida ou a ausência de uma escola institucional. Isto é, o vigor metodológico dos neoclássicos, aceito majoritariamente, eclipsou as potencialidades da explicação institucional, pois conseguiu pautar o que era aceito como ciência econômica e o que não era, privilegiando as táticas dedutivas em vez das indutivas e o enfoque sincrônico em vez do histórico. Contudo, pondere-se que a economia institucional, que de Veblen partiu, no mínimo serviu para redefinir o debate com elementos histórico-culturais desprezados por muitos dos economistas ortodoxos, sem falar na verificação empírica dos eventos, levada adiante pelos demais institucionalistas.

\section{Holismo metodológico}

Há algo mais no institucionalismo vebleniano: sua tendência holista. Para compreendê-la voltamo-nos para o conceito de ação instintiva presente na obra do autor. $\mathrm{O}$ instinto vebleniano não se resumiria às inclinações inconscientes apenas, também dele participariam a racionalidade - captada num prisma teleológico - e as normas sociais compostas historicamente pela sociedade. O fator responsável pela mobilização do sujeito social não se definiu adequadamente por qualquer desses níveis. A opção vebleniana, na verdade, dizia respeito às possibilidades de interação desses mecanismos, com algum destaque ora para a racionalidade, ora para os hábitos de pensamento institucionalizados.

No encadeamento de sua argumentação, Veblen permitiu-se furtar à tarefa de explicitar a noção de instinto e de hábito de modo acabado. Consequentemente, a possibilidade de situar um indivíduo contraposto à sociedade ou de situar a sociedade como moldura para os atos individuais aparentemente não se concretizou nos seus escritos. Não se manifestou em sua obra um caráter exclusivo para a natureza da ação, deixando em terreno movediço alguns pilares da sua reflexão social. Logo, não completamente alheio ao debate que se seguiria, dada sua vocação de polemista, Veblen abriu brechas para ataques que puseram em dúvida o rigor analítico de seu trabalho. Assim, objetivamos situar Veblen frente ao debate da natureza da ação, demonstrando que a sua dubiedade teórica pode ser substituída por uma sutil opção ao que se convencionou chamar na tradição sociológica de holismo metodológico. Para melhor entendimento dessa posição, avaliamos alguns pontos do pensamento vebleniano, contrapondo-os com as conclusões críticas expostas por Seckler (1977).

Em suas reflexões, Seckler procurou demonstrar que não há propriamente um único Veblen a se estudar. No que diz respeito à teoria social vebleniana, há duas inclinações explícitas no conjunto teórico do autor, garantindo "duas teorias 
mutuamente contraditórias"; se uma interpretação se voltasse apenas para uma das teorias seria "facilmente refutada com citações derivadas da outra", avalia o autor (Seckler, 1977, p. 110).

Tais posições remetem ao livre-arbítrio e ao holismo, que, eventualmente, podem significar alguma forma de determinismo. A primeira identificando a racionalidade efetiva como propósito para a ação; nesse caso, o indivíduo poderia demandar esforços com vistas a alcançar objetivos previamente mapeados. A segunda identificando forças exteriores ao sujeito como fatores de coerção da ação; aqui o indivíduo é subjugado por aquilo que está instituído em seu meio social. A primeira posição, Veblen vinculou-a ao método da "razão suficiente", a segunda, à "causa eficiente" (1969, p. 237).

Veblen estabeleceu um elo entre a razão suficiente e a economia neoclássica em sua perspectiva utilitarista. Criticou-os, como sabemos, pelo excessivo peso dado ao hedonismo em seu viés de análise e pela incapacidade no estabelecimento dos nexos causais com a totalidade social. A racionalidade pretendida pela economia neoclássica autonomizaria o sujeito da ação de modo a desarticulá-lo das relações culturais. O indivíduo ficaria compreendido na sua dimensão psicológica, logo, a pluralidade causal motivadora dos eventos dos quais poderia participar seria arrastada à condição de coadjuvante.

Porém, é importante considerar que, para Veblen, a racionalidade, mesmo quando se apresenta em seus textos, submerge com frequência diante das instituições sociais - por exemplo, a noção corrente em sua obra de que elementos sociais e culturais influenciam diretamente no esquema de gostos e prazeres do hedonismo humano. A razão suficiente, própria da tradição econômica predominante à época, tende a imaginar um indivíduo dotado de um exclusivo poder de apreensão do futuro imediato, cuja ação racional se constrói exclusivamente numa percepção teleológica que se distancia de qualquer compreensão causal.

A relação da razão suficiente corre tão somente desde o futuro (que é apreendido) até o presente e é de um caráter e força unicamente intelectual, subjetivo, pessoal e teleológico; enquanto a relação de causa e efeito corre em direção contrária, sendo seu caráter e força dados objetivos, impessoais, materiais. O esquema moderno de conhecimento, em sua totalidade, baseia-se definitivamente sobre a relação de causa e efeito; a relação de razão suficiente é admitida somente de modo provisório, como fator aproximado na análise, sempre com a reserva de que a análise deve se basear em termos de causa e efeito (Veblen, 1969, p. 238).

Seckler aponta, no entanto, que a crítica vebleniana pode ser amenizada se considerarmos as palavras do próprio autor, que, nas páginas anteriores do mesmo texto no qual debate sobre a economia ortodoxa, não deixa de saudar a 
racionalidade humana na conduta social. Diante das exigências do meio, a "conduta humana é concebida e interpretada como uma resposta racional" (Veblen, 1969, p. 234). Assim, Veblen parece indiretamente aceitar a razão e sua conduta teleológica, criticada pontualmente por ele mesmo quando associada à economia neoclássica.

A conduta da humanidade difere da conduta dos brutos por ser determinada por sensações antecipadas de prazer e dor, em lugar de sensações atuais. Desse modo, a conduta humana sai da seqüência de causa e efeito e cai na regra da razão suficiente. Em virtude dessa faculdade racional do homem, a conexão entre estímulo e resposta é teleológica ao invés de causal (Veblen, 1969, p. 235).

A oscilação de Veblen diante de duas posturas tão antagônicas estimulou dúvidas quanto ao seu propósito. Seckler, em particular, defendeu a tese de que as duas posições teóricas subsistem no pensamento vebleniano: o livre-arbítrio e o condicionamento social. Em sociologia, remeteríamos tal dilema ao que se convencionou chamar de individualismo metodológico e holismo metodológico. Para Seckler, Veblen abdicou de um posicionamento explícito quanto à natureza da ação e, assim fazendo, lançou dúvidas sobre a capacidade explicativa de seu projeto investigativo.

Criticou a economia dominante por construir um homem como um simples autômato que só respondia às forças de seu meio; [...] criticou esta mesma economia por estar baseada num propósito, o emprego do método da 'razão suficiente'. Então, quando Veblen se voltou para a construção de sua própria teoria, seu primeiro ato foi fazer da eleição um mero engano, já que, segundo ele, as eleições [escolhas] estão determinadas pela cultura, abarcando assim um mecanismo evolutivo de 'causa eficiente' (Seckler, 1977, p. 116).

Veblen atacou a razão por ser teleológica e por não contemplar a influência das forças sociais, segundo Seckler. Dessa forma, validou o peso de elementos exógenos na conduta individual, mas, de modo concomitante, permitiu que a racionalidade sutilmente ganhasse um status central frente ao cálculo de ganhos interessados para o agente.

A razão por apontar o primeiro e decisivo lugar para o prazer, antes do que para a dor, na determinação da conduta humana, aparece como aceitação (tácita) dessa doutrina otimista de uma ordem beneficente da natureza [o hedonismo], o qual o século dezenove teria herdado do dezoito (Veblen, 1969, p. 235).

O que poderíamos dizer desse Veblen pendular que num instante afirma e, aparentemente incerto daquilo que conclui, instantes depois se desautoriza? Em princípio, tanto menores seriam as certezas que de seus textos extrairíamos se maiores fossem as citações observadas. Porém, de imediato, sugerimos que, se ao nos aproximarmos dos seus escritos conseguimos ampliar as dúvidas quanto à sua 
estrutura metodológica, na mesma proporção e inversamente, tal aproximação viabiliza a relação de todo o seu conjunto conceitual, permitindo-nos dissipar muito das dúvidas que envolvem sua metodologia, apreendendo uma definição mais firme dos propósitos do autor. É dessa reflexão que partimos para defender uma posição contrária àquela apontada por Seckler.

Há um Veblen que se compõe de modo sutil no conjunto dos seus escritos. Sutileza compreendida somente numa visão que não se reduza aos particularismos. Um autor que não somente se posicionou quanto à natureza da ação - talvez com menor vigor do que muitos que a ele se opuseram ou que dele partiram -, mas que auxiliou na preparação de um terreno fértil para que frutificasse a tradição que na economia recebeu o nome de institucionalismo. Falamos aqui de um Veblen que concordou com o holismo metodológico na composição do seu pensamento. Um autor que apostou nas relações sociais matizadas numa perspectiva diacrônica e nos constrangimentos exógenos que se realizam sobre o indivíduo. Fecundar o institucionalismo na economia, fazendo-a gravitar em torno da história e das normas sociais, pôde, pelo menos em alguma medida, garantir à teoria vebleniana maior fundamentação do que Seckler suspeitou que tivesse.

Pensar sobre um Veblen holista requer alguns apontamentos. Em primeiro lugar, cabe ponderar que a aparente oscilação vebleniana quanto à natureza da ação pode ser mediatizada com a singular significância do século XIX para o desenvolvimento das ciências naturais e sociais. Talvez, nesse quadro histórico, possamos compreender a centralidade que o tema natureza da ação adquiriu nas discussões filosóficas até se cristalizar como um tema eminentemente sociológico.

Reconhecemos, em princípio, que, em alguma medida, o tema da natureza do conhecimento, retomado na tradição filosófica, sobretudo nos séculos XVII e XVIII, classicamente exposto no inatismo e no empirismo, possa ter transbordado para o tema natureza da ação. A razão suficiente, herdeira do inatismo, tornar-se-ia um sustentáculo do individualismo metodológico - não querendo, aqui, deslocar o peso do liberalismo político-econômico de modo mais específico. A causa eficiente, herdeira do empirismo, tornar-se-ia, por sua vez, a base sobre a qual se assentaria o holismo metodológico. O transbordamento dos dilemas suscitados pela natureza do conhecimento no tema natureza da ação parece ter sido, de algum modo, reflexo da filiação original das ciências sociais à sua matriz filosófica.

Desse modo, a aparente oscilação vebleniana, menos do que um equívoco, talvez possa ser compreendida como tomada de posição em terreno ainda pantanoso. A cristalização do tema natureza da ação ainda não se completara em definitivo nas ciências sociais de modo geral, portanto, menos ainda na economia do século XIX. Em outras palavras, a discussão não se socializara com clareza no âmbito acadêmico. Queremos dizer que, se a tradição individualista tornara-se 
robusta desde as primeiras horas do liberalismo, já no último quartel do século XVIII, a tradição holista, apesar de diluída em algumas formas de determinismo pelo século XIX afora, ainda não se instalara plenamente como preocupação sociológica e sequer econômica. A primeira tradição, que não impregnou a sociologia senão através da filosofia e da economia, parece ter ficado em compasso de espera para o jogo do debate com a segunda tradição. O último quartel do século XIX pôde definir os campos de atuação de cada universo disciplinar, assim como desdobrar o debate em cada área. Porém, recorde-se que foram, em grande medida, os clássicos da sociologia, Émile Durkheim e Max Weber, na aurora do século XX, os principais responsáveis por tonificar e dar as diretrizes gerais para o embate sobre a natureza da ação que se desenrolou posteriormente.

Nos desdobramentos desse circuito intelectual é que se fazia o combate vebleniano do individualismo na tradição econômica clássica e neoclássica. Não por outro motivo, o encadeamento argumentativo de Veblen abandonava as posições originais na qual fora formado, sob pesada orientação daquelas matrizes de pensamento econômico, para recriar um espaço de atuação que ainda não havia sido delimitado adequadamente na economia norte-americana de sua época considerando a restrita aventura do historicismo econômico no país, anterior ou contemporâneo das obras veblenianas. Em meio a essa atmosfera intelectual, Veblen aproxima a noção de homo economicus à noção de homo sociologicus. A demarcação desse novo espaço não se fez sem o uso de ferramentas interpretativas que já estavam sendo afiadas na sociologia, na antropologia ou na história; daí a incorporação do conhecimento etnológico da época, do princípio de causalidade histórica ou a absorção da ideia de uma arquitetura institucional com poder de coerção sobre indivíduo e sociedade, tema inequivocamente circunscrito ao conceito de norma social do universo sociológico.

Outro ponto de relevo das opções metodológicas de Veblen digno de nota é que, diante do quadro de época, o autor teve uma clara preocupação em levar seu trabalho para posições distantes do determinismo que ele supunha impregnar tanto as interpretações totalizantes quanto as históricas - recorde-se de suas críticas a Schmoller. Devemos considerar que a racionalidade ou a capacidade teleológica, por vezes sublinhadas em seus textos, adquiriu um papel importante desde seu conceito de instinto até às peculiaridades dos hábitos de pensamento.

Nesse sentido, é plausível também aceitar que muito da racionalidade presente em sua obra tenha servido como tentativa para frear o vício determinista que eventualmente podia atingir os que se prestavam a enumerar as qualidades das forças exógenas oriundas da cultura ou da história. Veblen dedicou-se a condicionar a razão em limites estreitos de modo que se evidenciassem os fatores sócio-históricos presentes nas relações humanas; a racionalidade, por vezes, teve seu papel destacado tanto quanto obscurecido. De um modo ou de outro, o autor 
jamais ofereceu ou celebrou os atributos da racionalidade como fontes exclusivas ou inaugurais das motivações humanas; o que torna possível ponderar que a suposta dubiedade observada por Seckler em muito se constituía numa espécie de antídoto vebleniano, ajuizando a razão para se opor às relações causais predeterminadas e permitindo uma melhor compreensão da causalidade nos moldes de uma ciência pós-darwinista.

É ainda provável que muito das opiniões de Veblen sobre a natureza da ação tenham sido formuladas tendo em vista, inicialmente, o diálogo do autor com as concepções kantianas. Num artigo de 1884, um jovem Veblen parece se encantar com a "noção de liberdade" presente, segundo ele, na Crítica da Razão Prática, tanto quanto se seduz pelo raciocínio sofisticado da "noção de determinismo estrito, em concordância com uma lei natural", definido na Crítica da Razão Pura $(1964 b \text {, p. 175 })^{16}$. Na perspectiva vebleniana, porém, a despeito da aparente incorporação das soluções kantianas, é significativo considerar que as condições básicas do conhecimento acerca da realidade se orientam pelas experiências materiais socialmente dadas. Isto é, Veblen contemplou a racionalidade humana como uma estrutura elementar que, se não antecipa, ao menos organiza as condições de um determinado conhecimento, condições, estas, que se associam pela experimentação ou pelas sensações.

Conceber o mundo no caminho exigido pelo julgamento reflexivo é concebêlo de modo a harmonizar [nossa interpretação] com as leis de nossa compreensão; o que significa adaptá-lo às nossas faculdades (Veblen, 1964b, p. 185).

Desse modo, o autor aludiu a um "julgamento reflexivo", que implica numa razão indutiva, capaz de sistematizar nosso conhecimento de acordo como nossas experiências (1964b, p. 180). Tal sistematização, segundo ele, deve ser compreendida como a disposição conveniente, em nossa inteligência, dos elementos materiais coletados por nossas demandas pessoais. Por essa razão o autor insistiu na investigação indutiva como provavelmente o meio mais adequado ou sustentável de avaliar possíveis regularidades do processo social em vista da interação cognitiva que produzimos a partir dos fenômenos observados (1964b, p. 193).

Entre as condições nas quais o teórico elaborou sua percepção da ação, devemos ao menos lembrar a sua receptividade aos estudos interdisciplinares. Não deixa de chamar a atenção dos leitores de Veblen que o autor, de acordo com a formação do debate à sua época, segue um percurso na exposição de suas ideias que abdica de maiores referências acadêmicas. A quantidade de autores citados é exageradamente limitada se comparada aos costumes e normas da academia. A

(16) Kant's critique of judgment (Veblen, 1964b, p. 175-193). 
intuição e a inspiração sociológica, antropológica ou histórica parecem, de alguma maneira, guiar o sentido totalizante do pensamento vebleniano. Talvez, por isso, nos chame a atenção, ainda, a forma como o autor expõe as suas ideias e o caráter fugidio de sua escrita. Não sem frequência, Veblen refere-se a um espaço/tempo indeterminado - selvageria primitiva, barbarismo ou era artesanal, por exemplo -, e, a partir daí, explica o desenrolar dos acontecimentos como se tivessem força de fatos históricos e, portanto, capazes de estabelecer padrões de conduta culturalmente aceitos por uma dada sociedade ${ }^{17}$. Em The Theory of the Leisure Class (1934) e The Instinct of Workmanship and the State of Industrial Arts (1989) ficam evidentes a retórica do autor, recriando aspectos da vida de alguma sociedade primitiva. Não se dá ao luxo de definir com exatidão o lugar ou o tempo daquilo que expõe; poucas são as vezes em que situa o que quer provar. $\mathrm{Na}$ argumentação de suas ideias, no entanto, sobressalta constantemente a inspiração das ciências sociais matizadas pela perspectiva histórica, resultando num encantamento que nos leva antes a concordar do que a refletir sobre suas colocações. De todo modo, o viés totalizante permanece forte o suficiente para garantir a solidez de sua cadeia argumentativa.

Eis o mote interdisciplinar do institucionalismo vebleniano. $\mathrm{O}$ autor pretendeu, com isso, apontar as falhas da natureza individual da ação como componente explicativo único nas relações sociais. Daí o viés totalizante de sua compreensão, gerando uma economia que não comungava mais com a interpretação restritiva e atomizada da tradição clássica e neoclássica. Tal propósito não se fez sem avanços e recuos intelectuais explicitados em seu texto com posições que parecem se anular. No entanto, a tensão latente que parece imputar ora ao indivíduo, ora às normas sociais o motor da ação supera-se em vista de um panorama geral do pensamento vebleniano.

Dilui-se o peso da racionalidade efetiva na proporção exata em que se eleva o status dos constrangimentos exógenos. Não por outro motivo as referências à razão e seu valor como atributo para a ação, para o instinto e na composição dos hábitos sempre são eclipsadas pelas referências aos padrões sociais, culturais ou institucionais que se impõem ao sujeito. Dá-se a marginalização de premissas clássicas da economia e a integração de componentes explicativos que se consagrariam na sociologia. Essa opção vebleniana foi condição essencial para que pudessem tomar corpo conceitos como instituição, institucionalização, dinâmica institucional, entre outros.

(17) A maioria dos cientistas sociais norte-americanos da segunda metade do século XIX, como Veblen, reflete a influência, difusa à sua época, do etnógrafo Lewis Henry Morgan (1818-1881), responsável por consagrar as noções de selvageria, barbarismo e civilização (Silva, 2010, p. 309). 


\section{Considerações finais}

Thorstein Veblen foi um cientista social de grande notoriedade em seu tempo. Esteve entre os mais comentados escritores das ciências sociais norteamericanas da primeira metade do século passado. Blaug admite que a tradição institucionalista era a grande linha teórica nos Estados Unidos nos anos precedentes à crise de 1929 (1999, p. 124). O autor foi inscrito no estreito círculo dos originais críticos do capitalismo, mas, concomitante a isso, não lhe desacompanhou o estigma de espécie estranha nas ciências sociais do período. Estranheza atribuída em parte ao distanciamento ou à ausência de qualquer sentido de pertencimento na interpretação do outro, em parte à agudeza crítica ao narrar a sociedade e seus paradoxos. Tratava-se de um "olhar estrangeiro", decompondo e dissecando a sociedade com "clareza e perspectiva" próprias de quem "havia nascido longe dela" (Heilbroner, 1969, p. 194). Galbraith admite Veblen como "figura reconhecidamente destrutiva", pouco afeito à "recomendação prática"; contudo, sentencia: "A atitude conscienciosamente crítica que hoje permeia algumas análises e observações econômicas americanas deve muito a ele" (Galbraith, 1989, p. 155).

Veblen morreu em agosto de 1929, antes da crise que desmontaria a economia norte-americana. Nesse ano, nos Estados Unidos, caiu por terra o encantamento singular que o liberalismo radical produziu na história do país. Enquanto vicejou, parecia ser sagrado e a solução única, e excepcionalmente óbvia, para a organização da economia. As críticas de Veblen atingiam diretamente tal organização. Combateu o modelo de investigação neoclássico que sustentava em boa medida o liberalismo radical daquele tempo, produzindo uma teoria que não só esboçou uma metodologia alternativa àquele tipo de análise, como, de resto, apontou para a deficiência do capitalismo na produção do avanço técnico e do bem comum. O autor sempre primou por anotar as falhas da disposição estrutural da economia do país que se refletiam em inúmeros aspectos: no consumo desenfreado, na voracidade do mercado financeiro, no poder excessivo do grande capital ou na capacidade predatória do proprietário no processo de acumulação. Muito embora seu arsenal crítico mirasse as situações de poder oriundas do mercado financeiro e do processo industrial, tomando os capitães da indústria ou os proprietários ausentes como alvos, sua crítica não deixou de alcançar uma dimensão cultural. Veblen avaliou de maneira mordaz o consumo exibicionista e a corrida pelo status entre os que procuravam se firmar na competitiva cena social de um país que crescia sem freios, mas que parecia abandonar as virtudes ascéticas de orientação protestante tão sólidas em outros tempos - o trabalho árduo, o comedimento, o êxito no empreendimento pelo mérito, etc.

Condensando as influências naturais de seu tempo, como o historicismo e o darwinismo, Veblen logrou extrair posições de ambas as tradições acadêmicas, 
fazendo-as ecoar em uma teoria institucional claramente antideterminista. A argumentação vebleniana procurou conciliar o peso do passado e sua influência na organização do repertório de época com um incentivo discreto ao indutivismo, isto é, à captação de referências históricas que pudessem melhor respaldar a compreensão da dinâmica econômica. De modo geral, a teoria social do autor redunda na clássica oposição entre o individualismo metodológico do Homo Economicus e o holismo do Homo Sociologicus, permitindo situá-lo num momento importante de um debate proveniente desde meados do século XIX pelo menos.

Essa mistura de elementos de análise, de temas ou de explicações curiosamente ocorre em um momento particular da história das ciências: até o final do século XIX, e talvez nas primeiras horas do XX, os campos científicos nas ciências sociais já estavam esboçados com alguma clareza, mas não cristalizados o suficiente. Veblen projeta o seu corpo de ideias nesse quadro particular. Logo, tornou-se a matriz de um discurso heterodoxo para a ortodoxa economia norteamericana daquele momento. De resto, aproximou-a da tradição sociológica, não da sociologia do país às voltas com o que sobrara do darwinismo social ou do assistencialismo clerical, mas da sociologia europeia que já caminhava a passos largos na definição de suas preocupações.

\section{Bibliografia}

ADORNO, Theodor W. Veblen's attack on culture. In: WOOD, John Cunningham (Ed.). Thorstein Veblen: critical assessments. New York: Routledge, 1994. v. 3.

ARIDA, Pérsio. A história do pensamento econômico como teoria e retórica. In: GALA, Paulo; REGO, José Márcio (Org.). A história do pensamento econômico como teoria e retórica: ensaios sobre metodologia em Economia. São Paulo: Editora 34, 2003.

BLAUG, Mark. História do pensamento econômico. Tradução Miguel D. C. Branco. Lisboa: Publicações Dom Quixote, 1990.

EDUSP, 1999.

Metodologia da economia. Tradução Afonso L. M. S. Lima. São Paulo:

DORFMAN, Joseph. Thorstein Veblen and his America. New York: The Viking Press, 1934.

DUGGER, William M. The origins of Thorstein Veblen's thought. In: WOOD, John Cunningham (Ed.). Thorstein Veblen: critical assessments. New York: Routledge, 1994. v. 1.

EDGELL, Stephen. Rescuing Veblen from Valhalla: deconstruction and reconstruction of a sociological legend. The British Journal of Sociology, v. 47, n. 4, Dec. 1996.

GALBRAITH, John Kenneth. Crônicas de um eterno liberal. Tradução Edna J. de Mello. Rio de Janeiro: Editora Nova Fronteira, 1980. 
GALBRAITH, John Kenneth. O pensamento econômico em perspectiva: uma história crítica. Tradução Carlos A. Malferrari. São Paulo: Pioneira e EDUSP, 1989.

GORDON, W. The role of institutional economics. In: WOOD, John Cunningham (Ed.). Thorstein Veblen: critical assessments. New York: Routledge, 1994. v. 2.

HEGENBERG, Leônidas. Explicações vientíficas: introdução à filosofia da ciência. São Paulo: Ed. Pedagógica e Universitária e EDUSP, 1973.

HEILBRONER, Robert. Introdução à história das idéias econômicas. Tradução Waltensir Dutra. Rio de Janeiro: Zahar Editores, 1969.

HODGSON, Geoffrey M. Economics and institutions: a manifesto for a modern institutional economics. Philadelphia: University of Pennsylvania Press, 1988.

v. XXXVI, n. 1, mar. 1998.

HOMAN, Paul T. La escuela institucional. In: SPENGLER, Joseph J.; ALLEN, William R. (Org.). El pensamiento económico de Aristóteles a Marshall. Madri: Editorial Tecnos, 1971.

HOSPERS, John. Introducción al análisis filosófico. Madri: Alianza, 1984.

LALLEMENT, Michel. Raízes alemãs da sociologia econômica. Tradução Leonardo Mello e Silva. Tempo Social - Revista de Sociologia da USP, São Paulo, v. 18, n. 1, jun. 2006.

LOSEE, John. Introdução histórica à filosofia da ciência. Tradução Borisas Cimbleris. Belo Horizonte: Ed. Itatiaia, São Paulo: EDUSP, 1979.

MONASTÉRIO, Leonardo. Guia para Veblen: um estudo acerca da economia evolucionária. Pelotas: EDUFPEL, 1998.

NISBET, Robert . Conservantismo. In: BOTTOMORE, T.; NISBET, R. História da análise sociológica. Tradução Waltensir Dutra. Rio de Janeiro: Zahar Editores, 1980.

PAULA, João Antônio de. Afinidades eletivas e pensamento econômico: 1870-1914. Revista Kriterion, Belo Horizonte, Departamento de Filosofia/UFMG, n. 111, jun. 2005.

REALE, Giovanni; ANTISERI, Dario. História da filosofia). São Paulo: Editora Paulus, 1991. v. 2.

ROSS, Dorothy. The origins of American social science. Cambridge: Cambridge University Press, 1997.

SCHUMPETER, Joseph A. História da análise econômica . Tradução A. M. Reis; J. L. S. Miranda; R. Rocha. Rio de Janeiro: Editora Fundo de Cultura, 1964. v. 3.

Fundamentos do pensamento econômico. Tradução Edmond Jorge. Rio de Janeiro: Zahar Editores, 1968. 
SECKLER, David. Thorstein Veblen y el institucionalismo: un estudio de la filosofia social de la economia. Cidade do México: Fondo de Cultura Económica, 1977.

SILVA, Vagner L. da. Arqueologia da sociologia econômica: a contribuição de Thorstein Veblen. Estudos de Sociologia, Araraquara, Unesp, n. 25, 2008.

- Fundamentos do institucionalismo na teoria social de Thorstein Veblen. Política \& Sociedade, Florianópolis, UFSC, v. 9, n. 17, 2010.

SPENGLER, Joseph J.; ALLEN, William R. El pensamiento económico de Aristóteles a Marshall. Madri: Editorial Tecnos, 1971.

TILMAN, Rick. Some recent interpretations of Thorstein Veblen's theory of institutional change. In: WOOD, John Cunningham (Ed.). Thorstein Veblen: critical assessments. New York: Routledge, 1994. v. 2.

VEBLEN, Thorstein Bunde. The theory of business enterprise [1 ed., 1904]. New York: Charles Scribner's Sons, 1932.

. The theory of the leisure class: an economic study of institutions [1 ed., 1899]. New York: The Modern Library, 1934.

. The Vested interests and the common man: the modern point of view and the new order [1 ed., 1919; publicado originalmente sob o título The Vested interests and the state of the industrial arts]. New York: A. M. Kelley, 1964a.

. Essays in our changing order [1 ed., 1934]. New York: A. Kelley, $1964 b$.

- A teoria da classe ociosa: um estudo econômico das instituições. Tradução Olívia Krähenbühl. São Paulo: Livraria Pioneira Editora, 1965a.

. The engineers and the price system [1 ed., 1921]. New York: A. M. Kelley, 1965b.

. Veblen on Marx, race, science and economics. The place of science in modern civilization and other rssays [1 ed., 1919; publicado originalmente sob o título The place of science in modern civilization and other essays). New York: Capricorn Books, 1969.

. The instinct of workmanship and the state of industrial arts [1 ed., 1914]. New

Brunswick: Transaction Publishers, 1989.

WALLER, JR. William T. The concept of habit in economic analysis. In: HODGSON, Geoffrey M. (Org.). The economics of institutions. Aldershot: E. Elgar Publishing, 1993. 